\title{
A murine model of xenotransplantation of human glioblastoma with imunosupression by orogastric cyclosporin
}

\author{
Alexandre M. Cunha ${ }^{1,2}$, Fernanda S. Nascimento ${ }^{1}$, Jane C.O.F. Amaral ${ }^{3}$, \\ Sandra Konig ${ }^{3}$, Crhistina M. Takiya ${ }^{4}$, Vivaldo M. Neto ${ }^{3,5}$, \\ Eduardo Rocha ${ }^{6}$, Jorge P.B.M. Souza ${ }^{1}$
}

\begin{abstract}
Several animal experimental models have been used in the study of malignant gliomas. The objective of the study was to test the efficacy of a simple, reproducible and low cost animal model, using human cells of glioblastoma multiforme (GBM) xenotransplantated in subcutaneous tissue of Wistar rats, immunosuppressed with cyclosporin given by orogastric administration, controlled by nonimunosuppressed rats. The animals were sacrificed at weekly intervals and we have observed gradual growth of tumor in the immunosuppressed group. The average tumor volume throughout the experiment was $4.38 \mathrm{~cm}^{3}$ in the immunosuppressed group, and $0.27 \mathrm{~cm}^{3}$ in the control one $(p<0.001)$. Tumors showed histopathological hallmarks of GBM and retained its glial identity verified by GFAP and vimentin immunoreaction. Immunosuppression of rats with cyclosporin was efficient in allowing the development of human glioblastoma cells in subcutaneous tissues. The model has demonstrated the maintenance of most of the histopathological characteristics of human glioblastoma in an heterotopic site and might by considered in research of molecular and proliferative pathways of malignant gliomas.
\end{abstract}

Key words: animal model, Wistar rats, cyclosporin, glioblastoma, xenotransplant.

\section{Modelo murino de xenotransplante de glioblastoma humano com imunossupressão utilizando ciclosporina orogástrica}

\section{RESUMO}

Vários modelos animais têm sido avaliados no estudo dos gliomas e até o momento nenhum pôde ser considerado ideal. O objetivo deste trabalho é verificar a eficácia de um modelo animal simples, reprodutível e de baixo custo. Utilizamos células humanas de glioblastoma multiforme (GBM) xenotransplantadas em ratos Wistar, submetidos a imunossupressão com ciclosporina administrada por via orogástrica. Células tumorais foram implantadas no tecido subcutâneo dos ratos imunossuprimidos com ciclosporina, sendo o controle feito em ratos não imunossuprimidos. Os animais foram sacrificados em intervalos semanais e foi observado crescimento progressivo do tumor no grupo imunossuprimido. A média do volume tumoral em todo o experimento foi de $4,38 \mathrm{~cm}^{3}$ no grupo imunossuprimido e $0,27 \mathrm{~cm}^{3}$ no grupo controle $(p<0,001)$. Os tumores apresentavam características histopatológica do GBM e mantinham sua identidade glial, verificadas por imunoreação para GFAP e vimentina. A imunossupressão dos ratos com ciclosporina

\section{Correspondence}

Alexandre Martins Cunha

Rua Prof. Rodolpho Rocco 225

21941-913 Rio de Janeiro RJ - Brasil

E-mail: a.m.cunha@uol.com.br

amcunha@hucff.ufrj.br

Received 7 February 2010

Received in final form 23 July 2010

Accepted 30 July 2010

\footnotetext{
'Division of Neurosurgery, Department of Surgery, Clementino Fraga Filho University Hospital, Federal University of Rio de Janeiro, Rio de Janeiro RJ, Brazil; ${ }^{2}$ Division of Neurosurgery, Department of Surgical Specialties, Pedro Ernesto University Hospital, State University of Rio de Janeiro, Rio de Janeiro RJ, Brazil; ${ }^{3}$ Department of Anatomy, Institute of Biomedical Sciences, Federal University of Rio de Janeiro, Rio de Janeiro RJ, Brazil; ${ }^{4}$ Department of Histology and Embriology, Institute of Biomedical Sciences, Federal University of Rio de Janeiro, Rio de Janeiro RJ, Brazil; ${ }^{5}$ National Institute for Translational Neuroscience, Ministry of Science and Technology, Brazil; ${ }^{6}$ Division of Nephrology, Department of Internal Medicine, Clementino Fraga Filho University Hospital, Federal University of Rio de Janeiro, Rio de Janeiro RJ, Brazil.
} 
foi eficiente em permitir o desenvolvimento do glioblastoma no tecido subcutâneo. Uma vez que o presente modelo mantém a maioria das características histopatológicas do glioblastoma humano, ele pode ser considerado em estudos que avaliem as vias moleculares e proliferativas dos gliomas malignos.

Palavras-chave: modelo animal, ratos Wistar, ciclosporina, glioblastoma, xenotransplante.

Glioblastoma multiforme (GBM) is the most frequent primary brain tumor and is classified by the World Health Organization (WHO) in the group of diffusely infiltrative astrocytomas, representing the most malignant subtype of them ${ }^{1-9}$. Understanding the mechanisms of angiogenesis, cellular migration and proliferative pathways might improve therapeutic development for the treatment of $\mathrm{GBM}^{10-12}$. Scientific knowledge of the biology of the gliomas has been evolving with the use of animal models ${ }^{13}$.

An ideal animal model for the study of gliomas must have some defined characteristics: growth rate and malignancy characteristics of the tumor should be reproducible; the time of the tumor induction should be relatively short and the survival time should be standardized; the tumor should present intraparenchymal growth that simulates glioma, showing invasion, neovascularity and no encapsulation; the tumor should grow well in culture and must be safe for the laboratorial handling; and cheap and small species must be preferable ${ }^{14,15}$. Although many animal models are available, none of them fills all above the described characteristics ${ }^{14,15}$.

The model of orthotopic xenotransplantation with human tumor cells in anergic or imunosuppressed animals is the best way to simulate the growth of human gliomas $^{16}$. The models of heterotopic transplant outside the central nervous system are frequently used, and the subcutaneous xenografts are useful and reproducible models that allow the study of molecular biology and genetic alterations in $\mathrm{GBM}^{17}$.
These models of subcutaneous implantation allow a fast tumor growth and an easy evaluation of the size and volume of the tumor, without need of the animal's sacrifice. Moreover, no major histopathological difference has been demonstrated between the tumors implanted in subcutaneous and in cerebral tissue ${ }^{18}$. Because of difference in the pattern and vascular architecture between the models of cerebral and subcutaneous implantation, and also of the absence of blood-brain barrier in the subcutaneous models, care has to be taken in extrapolating the results of studies with subcutaneous models to human brain gliomas ${ }^{19,20}$.

The main objective of the present work was to verify the utility of an experimental model of human glioblastoma cells xenotransplantation in subcutaneous tissue of Wistar rats, immunosuppressed with cyclosporine given by orogastric administration.

\section{METHOD}

\section{Tumor cells}

Tumour sample (GBM-95) was obtained from a patient with GBM treated at the Neurosurgery Division from University Hospital Clementino Fraga Filho and experimental use was approved by Ethical Committee from Brazilian Ministry of Health. The protocol of this study was also approved by the Committee of Ethics in Animal Researches of Department of Surgery of Federal University of Rio de Janeiro. Microscopically dissected tumor was transferred to tissue culture flasks containing culture me-
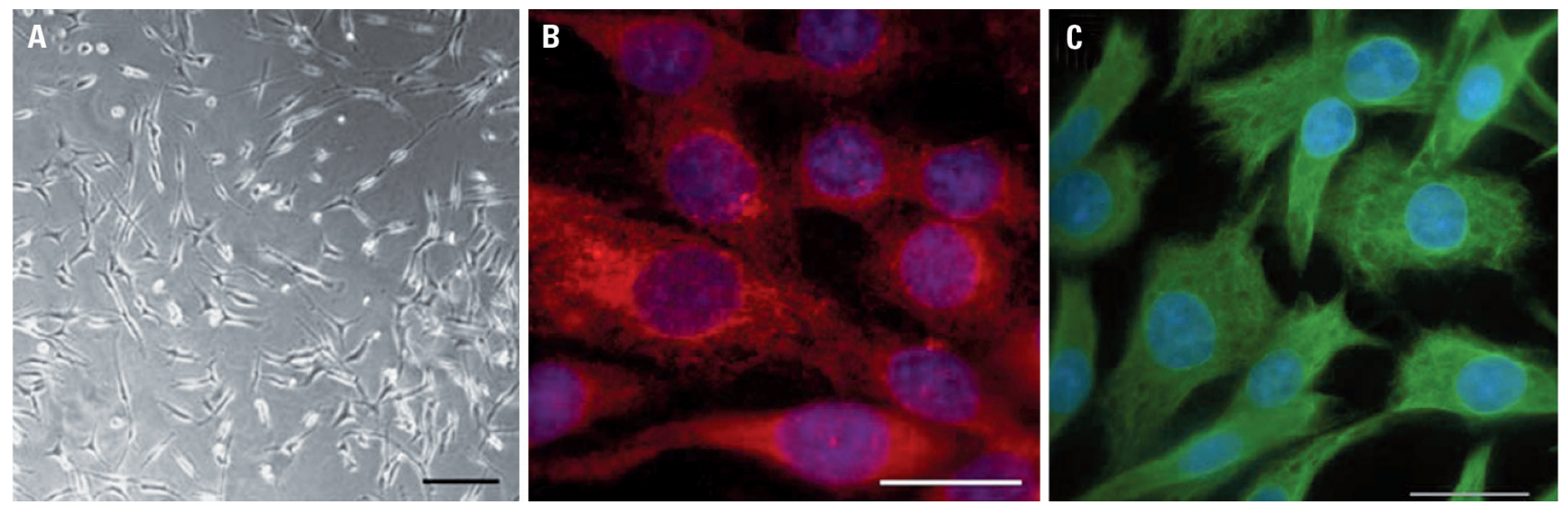

Fig 1. [A] Tumor cell culture of GBM-95 lineage used in the xenotransplantation. Scale bar: $150 \mu \mathrm{m}$. [B] Photomicrographies of Gbm 95 cells after GFAP immunoreaction (red) showing the predominant punctuate pattern, and [C] vimentin immunoreaction (green) showing the fibrillar pattern. Cells were stained with 40,6-diamidino-2-phenylindole for nuclei visualization (blue). Scale bar: 20 m. 
dium DMEM (Dubelcco's modified eagle medium) with $10 \%$ of fetal bovine serum (FBS) and maintained in a standard tissue culture incubator at $37^{\circ} \mathrm{C}$ and $5 \% \mathrm{CO}_{2}$. Briefly, when cellular growth achieved near $90 \%$ confluence, the cells were submitted to successive passages with trypsin treatment and then centrifuged and the pellet was resuspended with dimetilsulfoxide (DMSO) and FBS. They were maintained at a temperature of $-20^{\circ} \mathrm{C}$ for one hour and then stored in liquid nitrogen. We have previously described this detailed protocol in other study ${ }^{21}$.

Cells were defrosted in DMEN with 10\% FBS and cultured until use to xenotransplantation (Fig 1A). To do this, $10^{6}$ cells were used and we have used cells cultured in $14^{\text {th }}$ passage.

\section{Immunocytochemistry}

Immunocytochemistry was performed as described previously ${ }^{21}$. Briefly, cultured cells plated on glass coverslips were fixed with $4 \%$ paraformaldehyde for $30 \mathrm{~min}$ and permeabilized with $0.1 \%$ Triton X-100 in phosphatebuffered saline (PBS) for $5 \mathrm{~min}$ at room temperature. After blocking, cells were incubated with primary antibodies overnight at $4^{\circ} \mathrm{C}$ temperature, followed by PBS washes and incubation with specific secondary antibody conjugated with rhodamine: alexa fluor 488 goat anti-mouse, invitrogen, molecular probes; and fluorescein: alexa fluor 546 goat anti-rabbit, invitrogen, molecular probes. Primary antibodies used and dilutions were as follows: rabbit anti-cow, glial fibrillary acidic protein (GFAP), 1:500, Dako; monoclonal mouse, anti-vimentin, 1:200, Dako. In all immunostaining-negative controls, reactions were performed by omitting the primary antibody. No reactivity was observed when the primary antibody was absent.

\section{Experimental design}

Adult male Wistar rats weighting from 229 to 337 grammas were selected for the experiment. The animals were maintained in cages with free access to food and water. The rats were divided in two groups. The immunosuppressed group with twenty animals and the control group, not immunosuppressed, with fifteen rats. The immunossuppression was made by daily administration of cyclosporine through orogastric tube. The cyclosporine was diluted in olive oil and given at a dose of $5 \mathrm{mg} / \mathrm{kg}$. Immunosuppression was initiated $48 \mathrm{~h}$ prior the implantation of tumor cells and maintained until sacrifice of the animals. The rats in the control group received only olive oil for the same period.

The rats were anesthetized by intraperitoneal injections of ketamine $(10 \mathrm{mg} / \mathrm{kg})$ and xylazine $(2 \mathrm{mg} / \mathrm{kg})$, and $10^{6} \mathrm{GBM}$ cells from $14^{\text {th }}$ passage, were injected in a $1 \mathrm{ml}$ solution in subcutaneous tissue of the right flanks - inguinal region - of the animals.
The rats were sacrificed at weekly intervals, using the same anesthetic protocol, from the end of the first to the fourth week of experiment. Five rats were sacrificed each week in the immunosuppressed group and in the control group three rats were sacrificed at the end of first week, and four at the end of the next three weeks.

Tumor mass was identified, dissected, removed in bloc, measured and placed in 10\% neutral buffered formalin. When no lesion was identified, subcutaneous tissue was isolated and kept in the same formalin solution.

Tumor volume was estimated by multiplying anteriorposterior, lateral-lateral and superior-inferior measures of the lesion, and the result divided by two.

After resection of the flank tumor, abdomen and thoracic cavities were inspected and kidneys, liver, spleen and lungs were removed for macroscopic metastatic verification.

\section{Histopathologic analysis}

Tissues removed from the animals were maintained in the 10\% neutral buffered formalin for 96 hours. Afterwards, specimens were processed to hematoxylin and eosin (HE) staining and final neuropathological analysis was done in order to verify the presence of the glial component of the tumor and histopathological characteristics.

\section{Immunohistochemistry}

Biotin-streptavidin-peroxidase immunohistochemistry was performed in 3-4 $\mathrm{mm}$ thickness paraffin tumor sections. Sections were immunostained with anti-GFAP and anti-vimentin monoclonal primary antibodies (Dako, CA). The universal immunostaining system streptavidinperoxidase kit (Coulter, Fullerton, CA) was used to develop the reaction. Hematoxylin was used to stain and counterstain paraffin tumor sections and mounted with Permount. The primary antibody was omitted to provide negative controls.

\section{Statistical analysis}

Statistical analyses of the tumor volume differences between the two groups were made with t-test and Mann-Whitney rank sum test by Sigmastat program, with a statistical significance of $5 \%(\mathrm{p}<0.05)$.

\section{RESULTS}

\section{Immunocytochemistry}

The cells of GBM 95 are positive to both GFAP and vimentin. In vimentin immunoreaction a cytoplasmatic fibrillary pattern was observed, while in GFAP the cytoplasm staining had a more punctuated distribution (Fig $1 \mathrm{~B}$ and $1 \mathrm{C}$ ). These data show that GBM95 cells retaining its astroglial identity, also after many passages in culture. 

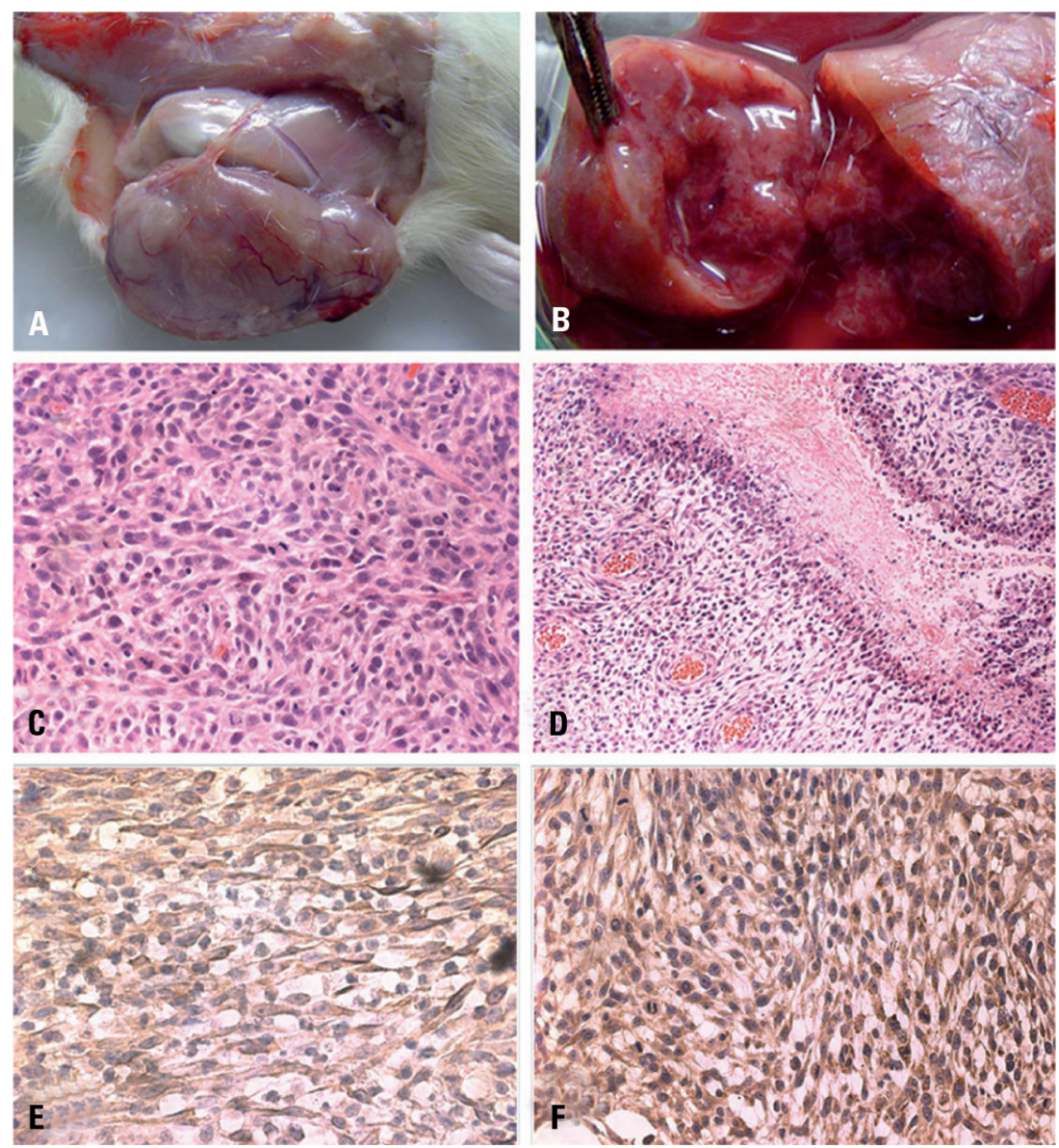

Fig 2. Tumor from rat after fourth week of immunosupresion. [A] Big and well circumscribed lesion, without infiltration of adjacent tissues. [B] The same lesion showing central necrosis. [C] Histopathologic staining showing mitosis and nuclear pleomorphism (HE 40X). [D] Pseudopalisading necrosis (HE 20X). [E] Immunohistochemistry showing GFAP expression $(40 \times)$. [F] Immunohistochemistry showing vimentin expression $(40 \times)$.

\section{Macroscopy}

In the non-immunosuppressed samples there was no measurable tumor growth in the first week. By the end of the second week there was tumor in all rats. At the third week, two animals had a small tumor and two others did

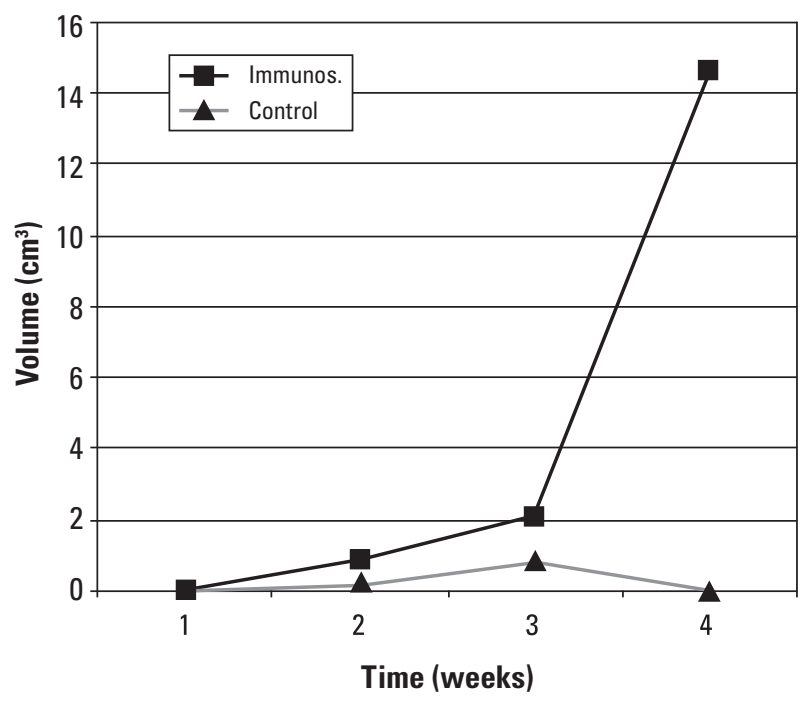

Fig 3. Average tumor volume in the both groups. not have any lesion. At the fourth week none of the rats had macroscopic tumor.

In the immunosuppressed group we have observed tumor in four of the five rats in the first week. We have verified presence of tumor in all five animals in the following weeks with progressive increase of mass volume toward the fourth week. At the fourth week all the rats had large lesions with evident central necrosis. The lesions were well circumscribed without infiltration of adjacent tissues in both groups - immunosuppressed (Fig $2 \mathrm{~A}$ and $2 \mathrm{~B}$ ), and control one.

The tumor volume measures have showed significant difference between the two groups in all experiment. The rate of the tumor growth was larger in the immunosuppressed group throughout all the four weeks. Tumor volume average in the immunosuppressed group was 4.38 $\mathrm{cm}^{3}$ and in the control group was $0.27 \mathrm{~cm}^{3}$. Comparing these data of the two groups throughout all the experiment, regardless the timing, there was a significant statistical difference between them $(\mathrm{p}<0.001)$.

A progressive increase of the tumor volume was verified in both groups until the third week. At the fourth week there was regression of tumor in the control group and marked growth of tumor volume in the immunosup- 
pressed group, with significant statistical difference between de two groups ( $\mathrm{p}=0.0059$ ) (Fig 3).

We have not detected any metastasis to lungs, spleen, liver or kidneys in none of the animals.

\section{Histopathology}

Histopathological analysis revealed presence of glial neoplasia in all the removed lesions. The tumors were characterized by elongated cells on a fibrillar background, with mitosis and nuclear pleomorphism (Fig 2C). They were well vascularized and inflammatory cells were seen at the periphery of the lesions. We observed the presence of central necrosis, including pseudopalisading necrosis, more evident in the largest lesions at the fourth week (Fig 2D).

There was no evidence of neoplasic tissue in the subcutaneous implantation area from animals that did not have macroscopic tumor.

\section{Immunohistochemistry}

The immunohistochemistry are strongly positive for GFAP and vimentin in lesions of both groups, demonstrating the glial nature of the developed tumors in rats (Fig 2E and 2F).

\section{DISCUSSION}

Animal models are a fundamental step in the study of neoplasias and xenotransplantation have been used with several configurations for human $\mathrm{GBM}^{15,22-26}$. Our design had the objective of testing a simple and practical experimental model, using Wistar rats immunosuppressed with cyclosporin for GBM human cells implantation in the inguinal subcutaneous tissue.

Cyclosporin promotes immunosuppression through its highly selective ability to inhibit the activation of $\mathrm{T}$ cells, by means of the inhibition of the calcineurin, and is largely studied in organs transplantation in order to decrease the index of rejection ${ }^{27,28}$. It has been demonstrated that cyclosporin inhibits the growth of murine glioma cells in vitro in dose dependent mechanism ${ }^{29}$. Apoptosis of tumoral cells, when exposed to the cyclosporin, seems to be mediated by the gene $\mathrm{p} 53^{30}$.

Inhibition of the tumoral cell proliferation was not observed in our model as well as induction of apoptosis. Our results clearly demonstrated that cyclosporin immunosuppression was related to tumor growth. A possible explanation for these differences is the fact that we have used the drug in doses next to the same of ones for clinical utilization ( $5 \mathrm{mg} / \mathrm{kg} /$ day) through orogastric administration in opposite of direct cell exposition as in vitro studies ${ }^{29,30}$.

Immunosupression of the animals receiving cyclosporin was clearly evident after observing GBM lesions in all the animals by the end of the fourth week, where- as in the control group there was complete involution of the tumors. The difference of tumor volume between both immunosuppressed and control groups, by the end of the fourth week, was statistically significant ( $\mathrm{p}=0.0059$ ). Moreover, the rate of the tumor growth was larger in the immunosuppressed group throughout all the four weeks. Comparing the tumor volume of the two groups, there was a significant difference between them $(\mathrm{p}<0.001)$, showing that the cyclosporin administration was determinant for the tumor development.

Our results have been similar to a previous work, where human glioblastoma cells were transplanted into brain and ocular region of cyclosporin immunosuppressed rats, by daily intraperitoneal injections at a dose of $5 \mathrm{mg} / \mathrm{kg}^{26}$. Xenotransplantation models of human glioblastoma multiforme in rats immunosuppressed with cyclosporin have also been used in the study of tumor invasion and in the development of new drugs, but we have found no articles in English literature where cyclosporin was given by orogastric route to the rats ${ }^{24,31,32}$.

The occurrence of systemic metastasis of GBM is rare, and isolated cases have been described in literature ${ }^{33,34}$. There was no evidence of metastasis in our study. We have not observed macroscopic evidence of metastasis in lymphatic ganglia, lungs, kidneys, spleen or liver in none of the studied animals.

Histopathological analysis of the tumors in our study showed well circumscribed but not encapsulated lesions, without dissemination or infiltration of tumors cells in the adjacent structures.

The glioma growth in subcutaneous tissues occurs basically by mass expansion and no cellular migration was observed. The GBM cells migration capacity is not determined only by genetic characteristics of the tumor cell but also depends of the interactions of its cells with the tissues microenvironment, which seems to be organ specific $^{35}$. Therefore, these models are not adequate for the study of cellular migration, but they are useful in the study of proliferation ${ }^{17,36}$.

We have verified the presence of histopathological characteristic aspects of human glioblastoma multiforme - hipercellularity, nuclear atypia, mitosis, abundant vascularization and necrosis, also with areas of pseudopalisading necrosis - that had been more intense at the fourth week. According to other studies ${ }^{18,35}$, endothelial proliferation is not usually observed in these type of models.

In conclusion, the experimental model of human GBM xenotransplantation in subcutaneous tissues of Wistar rats immunosuppressed with orogastric given cyclosporin is a simple, efficient and low cost model that reproduces much of the profile of human glioblastoma. It should not be used as a model for study of the biology of migration, due to the different matrix for cell-to-cell and 
cell-to-extracellular components interactions, but may contribute for future research in proliferative pathways of malignat glial tumors.

\section{REFERENCES}

1. Collins VP. Brain tumors: classification and genes. J Neurol Neurosurg Psychiatry 2004;75:2-11.

2. Daumas-Duport C, Scheithauer B, O'Fallon J, Kelly P. Grading of astrocytomas. A simple and reproducible method. Cancer 1998;62:2152-2165.

3. Deangelis LM. Brain tumors. N Engl J Med 2001;344:114-123.

4. Kleihues P, Louis DN, Scheithauer BW, et al. The WHO classification of tumors of the nervous system. J Neuropathol Exp Neurol 2002;61:215-225.

5. Louis DN, Holland EC, Cairncross JG. Glioma classification: a molecular reappraisal. Am J Pathol 2001;159:779-786.

6. Louis DN, Ohgaki H, Wiestler OD, Cavenee WK. WHO Classification of tumours of the central nervous system. Lyon: IARC; 2007.

7. Pietsch T, Wiestler OD. Molecular neuropathology of astrocytic brain tumors. J Neurooncol 1997;35:211-222.

8. Salcman M. Glioblastoma and malignant astrocytoma. In: Kaye AH, Laws ER (Eds). Brain tumors. New York: Churchill Livingstone; 1995:449-477.

9. Vajkoczy P, Menger MD. Vascular microenviroment in gliomas. J Neurooncol 2000;50:99-108

10. Ichimura K, Ohgaki H, Kleihues P, Collins VP. Molecular pathogenesis of astrocytic tumours. J Neurooncol 2004;70:137-160.

11. Lefrane F, Brotchi J, Kiss R. Possible future issues in the treatment of glioblastomas: special emphasis on cell migration and the resistance of migrating glioblastoma cells to apoptosis. J Clin Oncol 2005;23:2411-2422

12. Maher EA, Furnari FB, Bachoo RM, et al. Malignant glioma: genetics and biology of a grave matter. Genes Dev 2001;15:1311-1333.

13. Dai C, Holland EC. Glioma models. Biochim Biophys Acta 2001;1551:19-27.

14. Crafts D, Wilson CB. Animal models of brain tumors. Natl Cancer Inst Monog 1977:46:11-17.

15. Peterson DL, Sheridan PJ, Brown Jr. WE. Animal models for brain tumors: historical perspectives and future directions. J Neurosurg 1994;80:865-876.

16. Goldbrunner RH. Models for assessment of angiogenesis in gliomas. J Neurooncol 2000;50:53-60

17. Leuraud P, Taillandier L, Aquirre-Curz L. Correlation between genetic alterations and growth of human malignant glioma xenografted in nude mice. Br J Cancer 2003:89:2327-2332.

18. Watanabe K, Sakamoto M, Somiya M, Amin MR, Kamitani H, Watanabe T. Feasibility and limitations of the rat model by $\mathrm{C} 6$ gliomas implanted at the subcutaneous region. Neurol Res 2002:24:485-490.

19. Arosarena O, Guerin C, Brem H, Laterra J. Endothelial differentiation in intracerebral and subcutaneous experimental gliomas. Brain Res 1994;640: 98-104.

20. Bersen HJJA, Rijken PFJW, Hagemeier NEM, Van Der Kogel AJ. A quantita- tive analysis of vascularization and perfusion of human glioma xenografts at different implantation sites. Microvasc Res 1999:57:244-257.

21. Faria J, Romão L, Martins S, et al. Interactive properties of human glioblastoma cells with brain neurons in culture and neuronal modulation of glial laminin organization. Differentiation 2006;74:562-572.

22. Bigner SH, Humphrey PA, Wong AJ, Vogelstein B, Mark J, Friedman HS, et al. Characterization of the epidermal growth factor receptor in human glioma cell lines and xenografts. Cancer Res 1990;50:8017-8022.

23. Engebraaten $\mathrm{O}$, Hjortland $\mathrm{GO}$, Hirschberg H, Fodstad O. Growth of precultured human glioma specimens in nude rat brain. J Neurosurg 1999;90:125-132.

24. Guillamo JS, Lisovoski F, Christov C, et al. Migration pathways of human glioblastoma cells xenografted into the immunosuppressed rat brain. J Neurooncol 2001;52:205-215

25. Krushelnycky BW, Farr-Jones MA, Mielke B, McKean JD, Weir BK, Petruc KC. Development of large-animal human brain tumor xenograft model in immunosuppressed cats. Cancer Res 1991;51:2430-2437.

26. Mathiesen T, Collins VP, Olson L, Granholm L. Prolonged survival and vascularization of xenografted human glioblastoma cells in the central nervous system of cyclosporine A treated rats. Cancer Lett 1989:44:151-156.

27. Calne R. Cyclosporine as a milestone in immunosuppression. Transplant Proc 2004:36(Suppl):S13-S15.

28. Matsuda S, Koyasu S. Mechanisms of action of cyclosporine. Immunopharmacology 2000;47:119-125.

29. Moseniak G, Figiel I, Kaminska B. Cyclosporin A, an immunosuppressive drug, induces programmed cell death in rat C6 glioma cells by a mechanism that involves the AP-1 transcription factor. J Neurochem 1997:68:1142-1149.

30. Pyrzynska B, Serrano M, Martinez AC, Kaminska B. Tumor suppressor p53 mediates apoptotic cell death triggered by cyclosporin A. J Biol Chem 2002;277:14102-14108

31. Strojnik T, Kavalar R, Lah TT. Experimental model and immunohistochemical analyses of U87 human glioblastoma cell xenografts in immunosuppressed rat brains. Anticancer Res 2006;26:2887-2900.

32. Yoshida $\mathrm{D}$, Takahashi $\mathrm{H}$, Teramoto $\mathrm{A}$. Inhibition of glioma angiogenesis and invasion by SI-27, an anti-matrix metalloproteinase agent in a rat brain tumor model. Neurosurgery 2004;54:1213-1220.

33. Mourad PD, Farrel L, Stamps LD, Chicoine MR, Silbergeld DL. Why are systemic glioblastoma metastases rare? Systemic and cerebral growth of mouse glioblastoma. Surg Neurol 2005;63:511-519.

34. Schweitzer T, Vince GH, Herbold C, Roosen K, Tonn JC. Extraneural metastases of primary brain tumors. J Neurooncol 2001;53:107-114.

35. Antunes L, Angioi-Duprez KS, Bracard SR, et al. Analysis of tissue chimerism in nude mouse brain and abdominal xenograft models of human glioblastoma multiforme: what does it tell us about the models and about glioblastoma biology and therapy? J Histochem Cytochem 2000;48:847-858.

36. Killion JJ, Radinsky R, Fidler IJ. Orthotopic models are necessary to predict therapy of transplantable tumors in mice. Cancer Metastasis Rev 1998; $17 \cdot 279-284$ 